\title{
HOLD HEADING POSITION SYSTEM OF UNDERWATER REMOTELY OPERATED VEHICLE BASED ON PID
}

\author{
Parama Diptya Widayaka*, Akbar Sujiwa \\ Department of Electrical Engineering \\ University of PGRI Adi Buana Surabaya \\ *Corresponding email address: diptyawidayaka@unipasby.ac.id
}

\begin{abstract}
Underwater remotely operated vehicle mainly used to help human for underwater activities such as underwater exploration, underwater maintenance, and underwater search and rescue. Underwater remotely operated vehicle also used for education, entertainment, and competitions. In some case especially for an important or highly risk tasks, the ROV applied some functions to improve and optimize the use of the ROV for some missions. This paper presents a heading hold system which is applied in the ROV to maintain heading position or pose of the robot. Using a GY-271 compass sensor to read the data of ROV heading position, microcontroller Arduino mega 2560 as a central processing unit and PID controller as a feedback controller to maintain ROV on desired position by controlling thruster speed and direction. The experiments give a result of the control system using PID by $5 \%$ error for the ROV to maintain heading position in steady position.
\end{abstract}

Keywords: Underwater Remotely Operated Vehicle, PID, GY-271 Compass, Arduino mega 2560

\section{INTRODUCTION}

The developments of robotic technology over the world growing fast especially underwater remotely operated vehicle. According to Marine Technology Society ROV committee's in "Operational Guidelines for ROV's" (1984) and The National Research Council Committee's in "Undersea Vehicle and National Needs" (1996), the definition of ROV is an underwater robot controlled by operator, to keep safe the robot on the dangerous environment during some missions or tasks [1]. Nowadays, tethered or un-tethered smallsize underwater vehicle mainly used in various area [2]. ROV is able to doing mission several meters underwater which has ability to observe better than human [3]. ROV divided into several divisions based on dimension, weight and strength which categorize as micro, mini, general, light work class, heavy work class and trenching ROV [4]. ROV can be used as a tool to observe underwater environment, search and rescue, and underwater maintenance. In other hand, ROV can be used as an education media, entertainment, and competitions. As an underwater observation vehicle, underwater ROV need to be embedded an automatic system to optimize the function of the ROV. This research presents an ROV with automatic control system to maintain its heading pose. Hold heading position system applied on some ROVs such as OpenROV. OpenROV is an open-source and low-cost underwater vehicle mostly used by communities or professionals and amateur underwater exploration [10]. Hold heading position system is one of several control systems applied in ROV. Heavy class ROV embedded advance automatic control system called station keep system with heading hold position system applied inside the ROV. ROV with station keep system allow to control the ROV attitude, depth, and heading pose using some sensors. This research presents the heading hold position system using compass sensor to maintain ROV heading position by controlling the sidethruster of the ROV.

\section{RESEARCH METHODS}

This research developed an underwater remotely operated vehicle with automatic control system to control heading position of the ROV by using GY-271 compass sensor as a parameter for PID control method which applied in ROV as feedback controller to maintain ROV heading in steady water condition.

\section{Remotely Operated Vehicle}

1| BEST, Vol. 02, No. 2, 2020 
The proposed underwater ROV in this research design completed in 3D software as illustrated in Figure. 1 which has 4 movement thrusters that assigned 2 thrusters for horizontal movement and 2 thrusters for vertical movement.
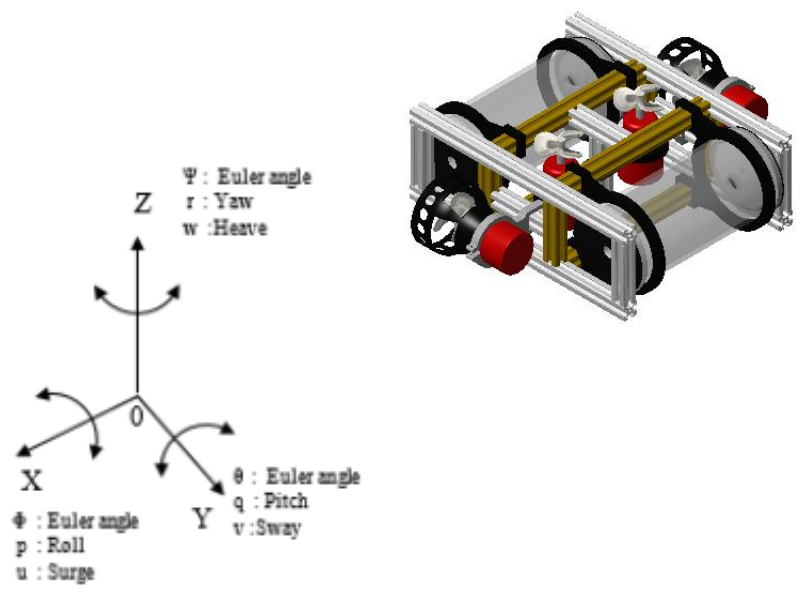

Figure 1. ROV Design

The ROV frame material constructed by Aluminum profile $20 \mathrm{~mm} \times 20 \mathrm{~mm}$. $5 \mathrm{~mm}$ thick with $90 \mathrm{~mm}$ diameter inside of acrylic tube called waterproof electronic tube is used for hardware placement which contain microcontroller, motor driver, camera, and sensors as can be seen in Figure 2. In other hand, waterproof electronic tube can be used for ROV buoyancy to make the ROV default

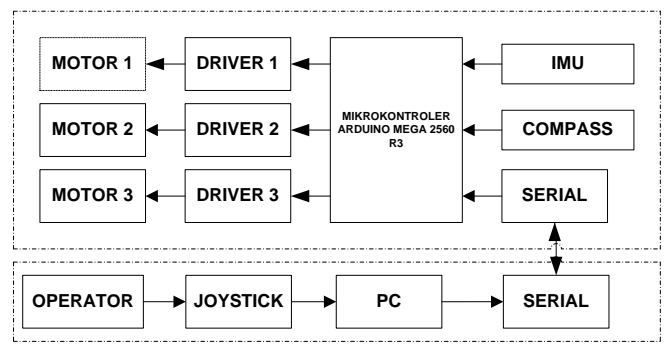

position in floating position.

Figure 2. ROV System Diagram

The ROV system consist of 2 parts, Ground control system and ROV system itself. As we can see in Figure 2., the ground control system has a joystick as the remote control for the operator to operate the ROV connected to a laptop or PC which develop an application to send the data from joystick to the robot using serial communication and the ROV send sensor data through $10 \mathrm{~m}$ cable.

ROV using Horizontal Thrust vector which is given forces produced by horizontal thruster of the vehicle to move. Drag and thrust are forces that affect the ROV while doing movement underwater. Thrust is a force to make the ROV move to another position underwater meanwhile drag is a force as a result of fluid pressure that occurs when vehicle moves through a fluid. Force that occurs when moving or maneuvering of ROV can be seen on a free-body diagram as shown in Figure 3.

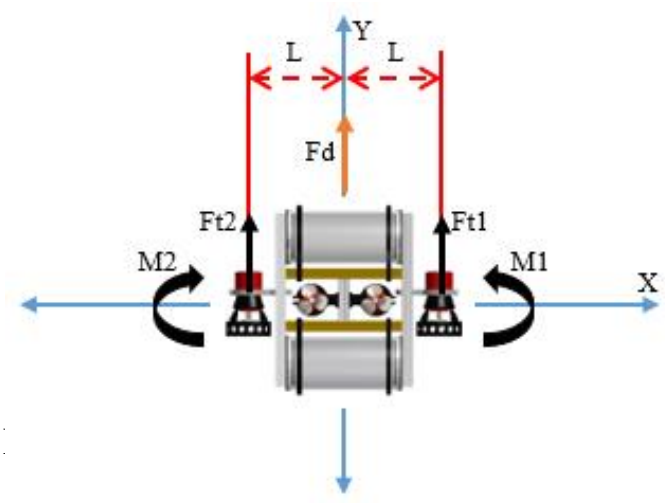

Based on free-body diagram in Figure 3, to move straight, a force of $\sum \mathbf{F}$ is needed on the Fy axis where the value of $\sum \mathbf{F}$ generated by the amount of thrust generated by thruster 1 (Ft) and thruster 2 (Ft2). Apart from making forward movements, there are movements to turn left and turn right. To turn left, the ROV must have a moment (M) on the center of gravity on the z-axis. Turning left movement carried out by utilizing the thrust generated by thruster 1 (Ft1) against the rotating axis in z-axis with the length of the arm between thruster 1 and the rotating axis of $\mathrm{L}$ to produce a moment M1 where the magnitude of M1 is the amount of force generated by thruster 1 multiplied by the length of the arm of $\mathrm{L}$ so that the vehicle can make left turn. For right turn movements, the method works the same as for the movement to turn left that to get a right turn moment of M2 by multiplying the amount of thruster 2 force $(\mathrm{Ft} 2)$ by the length of the arm by $\mathrm{L}$ so that the vehicle can turn right.

\section{PID Controller}

Underwater vehicle using PID control system consists of three control parameters, proportional, integral and derivative parameter to control the movement of underwater vehicle. PID controller calculates the error value that occurs at the output 


\section{BEST}

against a predetermined input setpoint. If the parameter values in the PID controller are not correct, the control process will become unstable [5]. The schematic of the PID control can be seen in the image below.

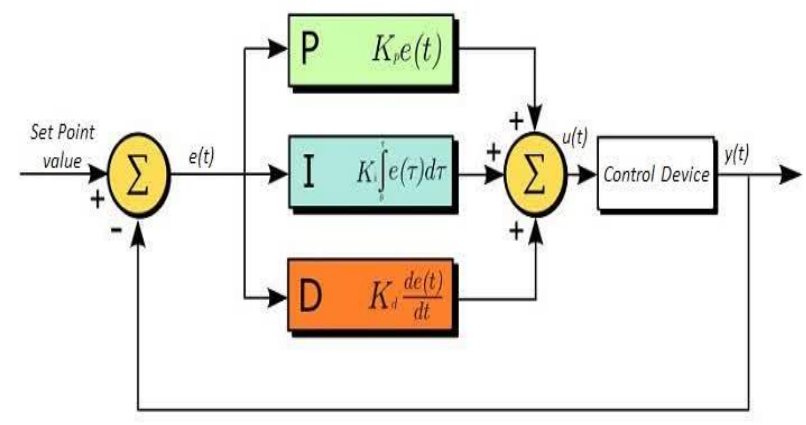

Figure 4. PID Controller Scheme

As can be seen in Figure 4. that the error data obtained from the reduction in the output generated from the compass sensor as feedback on the underwater vehicle with the setpoint value. From Figure 4, the equation for PID control is obtained as follows:

$u(t)=M V(t)=K_{p} e+\int_{0}^{t} e(\tau) d \tau+T_{d} \frac{d}{d t} e(t)$

The function of the proportional controller $(\mathrm{Kp})$ is to have the effect of reducing the rise time but not removing steady state errors, the integral controller (Ki) will have the effect of removing steady state but the transient response will deteriorate, while for the derivative controller $(\mathrm{Kd})$ it will give the effect of increasing stability. system, reduce the overshoot, and increase the transfer response where the effect of each controller can be seen in Table 1 .

\begin{tabular}{c|c|c|c|c|}
$\begin{array}{c}\text { Closed } \\
\text { Loop } \\
\text { Respons } \\
\text { e }\end{array}$ & $\begin{array}{c}\text { Rise } \\
\text { Time }\end{array}$ & $\begin{array}{c}\text { Overshoo } \\
\mathrm{t}\end{array}$ & $\begin{array}{c}\text { Waktu } \\
\text { turun }\end{array}$ & $\begin{array}{c}\text { Kesalaha } \\
\text { n } \\
\text { keadaan } \\
\text { tunak }\end{array}$ \\
\hline $\mathbf{K p}$ & Menurun & Meningkat & $\begin{array}{c}\text { Perubahan } \\
\text { kecil }\end{array}$ & Menurun \\
\hline $\mathbf{K i}$ & Menurun & Meningkat & $\begin{array}{c}\text { Meningka } \\
\mathrm{t}\end{array}$ & Hilang \\
\hline $\mathbf{K d}$ & $\begin{array}{c}\text { Perubaha } \\
\mathrm{n} \text { kecil }\end{array}$ & Menurun & Menurun & $\begin{array}{c}\text { Perubahan } \\
\text { kecil }\end{array}$ \\
\hline & & & & \\
\hline
\end{tabular}

\section{Hold Heading Position System}

The Hold Heading Position system is a system that functions to maintain a pose in an underwater remotely operated vehicle and can also change the position facing the ROV to the specified position. When the system is working, the ROV will respond to changes in the Heading position automatically which can be measured by a compass sensor by utilizing the horizontal thrust force to maintain the heading position [6]. If the ROV vehicle is given interference by changing the position of the direction facing the ROV, then the ROV will automatically make a movement to keep the direction facing so that it remains in the predetermined position. In this experiment the hold heading position control system is applied in a stationary state.

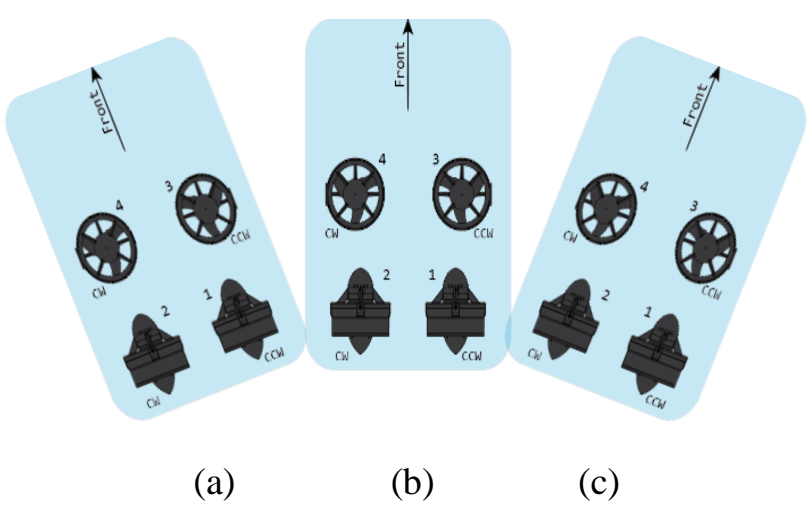

Figure 5. Hold Heading Position Mechanism

(a). ROV pose to the left

(b). Position hold

(c). ROV pose to the right

Figure 5. above is a representation of the position of the direction facing the ROV vehicle where point (b) is the predetermined setpoint position while points (a) and (c) represent the direction of the disturbance facing the ROV. If the ROV position is facing to the left, then thruster $2(\mathrm{Ft} 2)$ will give the ROV backward thrust and thruster 1 (Ft1) will provide forward thrust to make the vehicle move towards the right and vice versa. The block diagram of the Hold Heading Position system can be seen in Figure 6 . 


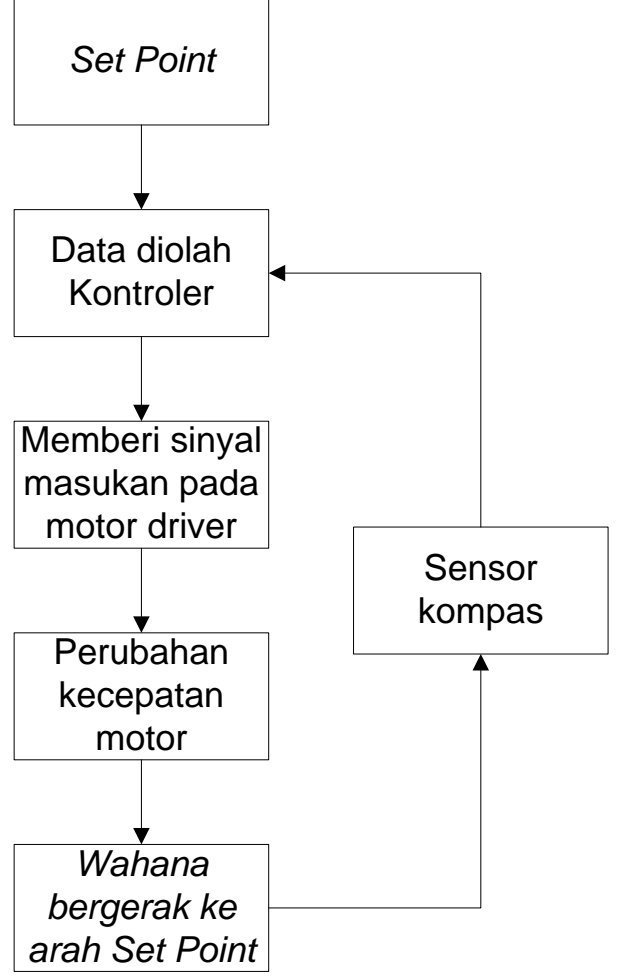

Figure 6. System Block Diagram

Figure 6.is a flow chart of the Hold Heading Position control system where the data starts from the input set point that has been previously determined by the operator and then received by the microcontroller that has been immersed in the ROV vehicle then the set point value is compared with the reading on the compass sensor. Then it will provide an input signal to the motor driver which will change the rotation speed of the motor. The result is a change in the position of the direction facing the ROV vehicle which will be detected by the compass sensor and returned to the microcontroller to be processed again and so on.

\section{RESULTS AND DISCUSSION}

\section{System Testing without Disturbance}

In this test to get the right parameter value so that the ROV vehicle can have a good response based on the set point reference for implementing the Hold Heading Position control system. In testing the Hold Heading Position control system, by placing the ROV vehicle on the surface of the water to facilitate testing. Below is a graph of the actual data response to the compass set point reference on the ROV vehicle. Figure 7 is a graph of the actual response data to the set point.

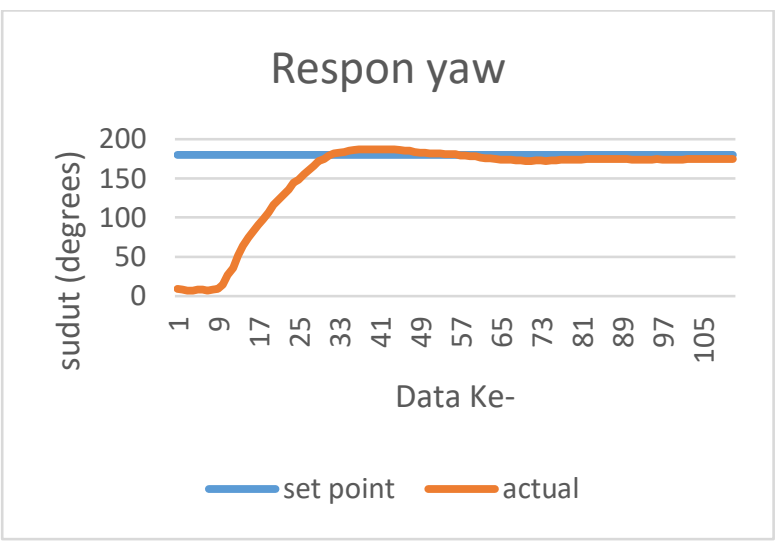

Figure 7. Control response without disturbance

In the experiment above, it is the movement of the angle to the yaw axis with a sampling time of $500 \mathrm{~ms}$ where the reference angle is set at 180 degrees and the actual angle is 0 degrees. It can be seen from Figure 8 that it is a graph of the response to the change in the actual angle to the reference angle, where the vehicle moves from a 0 degree angle to a 180 degree angle with constant parameters $\mathrm{KP}=3, \mathrm{KI}=0.05$, and $\mathrm{KD}=0.5$. In the response graph shown in Figure 4.6, it can be seen that the yaw response that occurs is quite good and there is no oscillation that is too large so it can be said that it has a good enough response to go to the predetermined set point.

\section{System Testing with Disturbance}

In this test, several interruptions are given to observe the response when the vehicle returns the actual position to its original position. In Figure 8 is a response graph by providing interference to the vehicle.

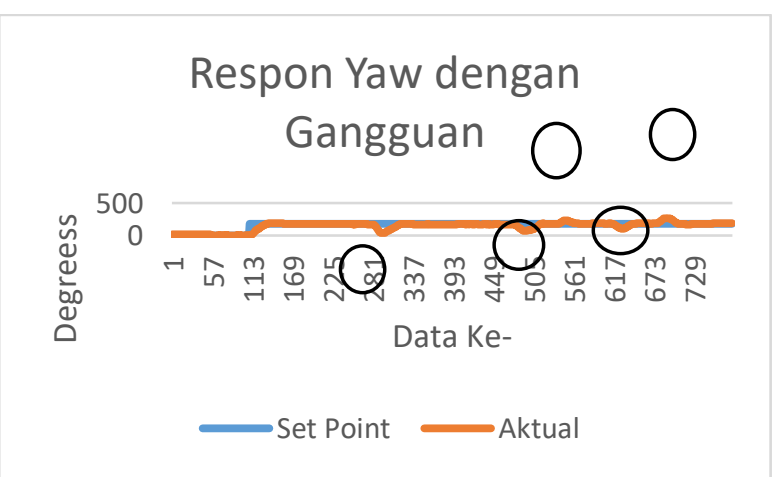

Figure 8. Control response with disturbance 


\section{BEST}

As can be seen in Figure 8 above, the response of the vehicle to the reference is quite good and by experimenting with giving interference by changing the pose position with the same parameters, namely $\mathrm{KP}=3, \mathrm{KI}=0.05$, and $\mathrm{KD}=$ 0.5 the vehicle provides resistance to return to the heading position that was set earlier. With a set point value of 180 degrees then a disturbance is given by changing the face position less than 180 degrees, the vehicle can return to the set point properly as well as when the vehicle is faced with an actual value greater than 180 degrees, the vehicle can return to the set point position. . In the circle on the graph is the overshoot that occurs, where to eliminate the overshoot using a derivative controller because the derivative controller functions to dampen the oscillations that occur in the application of Hold Heading Position.

\section{System Testing with Setpoint Changes}

In this test, several changes in the set point were given when the vehicle was stationary to observe the response when the vehicle moved to follow the set point. The response of the actual angle change to the reference can be seen in Figure 9.

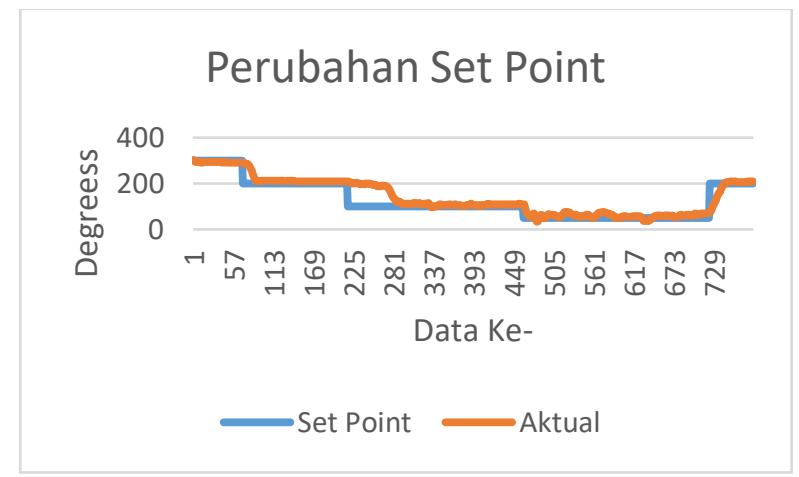

Figure 8. Control response with setpoint changes

As can be seen in Figure 8, the vehicle response to changes in the reference value is quite good with the same parameters, namely $\mathrm{KP}=3, \mathrm{KI}=0.05$, and $\mathrm{KD}=0.5$, the vehicle responds to the change in the reference angle set point. In the picture above there is a gap that occurs in the 229-305 data, this is because the test was not carried out in a large pool but only in a tub with a size of $1.5 \mathrm{mx} 1.5 \mathrm{mx} 1.5 \mathrm{~m}$ so that when the vehicle makes movements it often collides with the tub wall. The circle shown in the image above is the change in the actual angle to the reference which had a delay because when the set point was changed, the ROV hit the trough wall so that the actual response could change in the 305th data. To keep the vehicles from colliding with the help of pushing the rides so that there is no collision.

\section{CONCLUSION}

From the above research it can be concluded that the control system can be said to run well with the constant parameter $\mathrm{KP}=3, \mathrm{KI}=0.05$, and $\mathrm{KD}$ $=0.5$. In the experiment, there was an overshoot value of $5 \%$. It is advisable to carry out continuous research and also need to add controls to stabilize pitch and roll. For maximum performance of the vehicle, a dive movement in the ROV is required by controlling the vertical thruster to increase depth. It takes a good electronic component shield to avoid leakage during the dive.

\section{REFERENCE}

[1] Gitakarma, M.S., Ariawan, K.U., Wigraha, N.A., 2014, "Alat Bantu Survey Bawah Air Menggunakan AMOBA, Robot Berbasis ROV",Fakultas Teknik dan Kejuruan, Singaraja.

[2] Wang, Wei., 2006, "Autonomous Control of a Differential Thrust Micro ROV", Mechanical Engineering, University of Waterloo, Canada.

[3] Susanto, Tri, Ronny Mardiyanto, and Djoko Purwanto. "Development of Underwater Object Detection Method Base on Color Feature." 2018 International Conference on Computer Engineering, Network and Intelligent Multimedia (CENIM). IEEE, 2018.

[4] Samosir, T.H., Masengi, K.W.A., Kalangi, P.N.I., Iwata, Masamitsu, Mandagi, I.F., 2012, "Aplikasi Remotely Operated Vehicle (ROV) dalam penelitian kelautan dan perikanan di sekitar perairan Sulawesi Utara dan Biak Papua”, Jurnal Ilmu dan Teknologi Perikanan Tangkap.

[5] Pitowarno, Endra., 2006, "ROBOTIKA, Desain, Kontrol, dan Kecerdasan Buatan", Yogyakarta, Penerbit: Andi.

[6] Rochman, Sagita, and Akbar Sujiwa. "Peningkatan Daya Output Generator Listrik Tipe Afpmg Pada Putaran Rendah Menggunakan 3 Rotor Dan 2 Stator."

[7] Sujiwa, Akbar, and Sagita Rochman. "Pengembangan Sistem Kontrol Serta 
BEST

Journal of Applied Electrical \& Science Technology - University of PGRI Adi Buana

p-ISSN 2715-2871

e-ISSN 2714-5247

Monitoring Suhu dan Volume Air Berbasis

Web Pada Perangkat Desalinasi Air

Laut." SNHRP (2019): 1-9. 